\title{
ELSEVIER_MARSYS_2604
}

\section{Seasonal cycle of plankton production in the lberian margin based on a high resolution ocean model}

Rosa Reboreda $a^{a}$ *

rosa.reboreda@ua.pt

Rita Nolasco

rita.nolasco@ua.pt

Carmen G. Castro

cgcastro@iim.csic.es

Xosé A. Álvarez-Salgado ${ }^{b}$

xsalgado@iim.csic.es

Nuno G.F. Cordeiro

ngfc@ua.pt

Henrique Queiroga ${ }^{c}$

henrique.queiroga@ua.pt

Jesus Dubert ${ }^{a}$

jdubert@ua.pt

aCESAM and Departamento de Física, Universidade de Aveiro, Campus de Santiago, 3810-194, Aveiro, Portugal

bIIM-CSIC, Instituto de Investigacións Mariñas, Eduardo Cabello 6, 36208 Vigo, Spain

'CESAM and Departamento de Biologia, Universidade de Aveiro, Campus de Santiago, 3810-194, Aveiro, Portugal

${ }^{*}$ Corresponding author.

\section{Abstract}

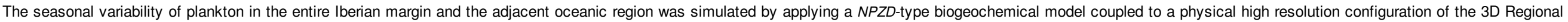

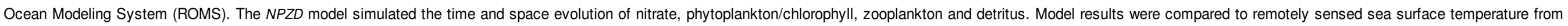

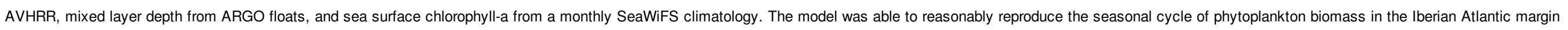

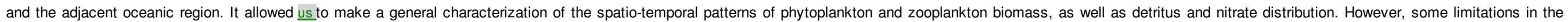

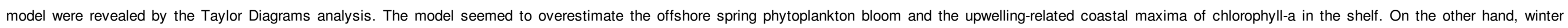

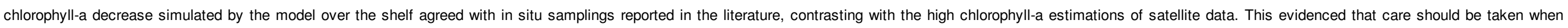
validating model results in the Iberian coastal region using satellite chlorophyll-a products, particularly in winter.

Keywords: Chlorophyll; Biogeochemical modeling; ROMS; Upwelling; East Atlantic; Iberian Margin; Portugal; Spain

\section{Introduction}

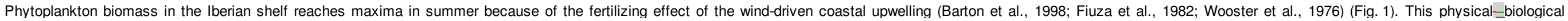




\section{ELSEVIER_MARSYS_2604}

interaction makes the Iberian margin a very productive ecosystem, characterized by a rich marine biodiversity and important fishing and shellfish resources (Figueiras et al., 2002; Santos et al., 2005; Tenore et al., 1995).

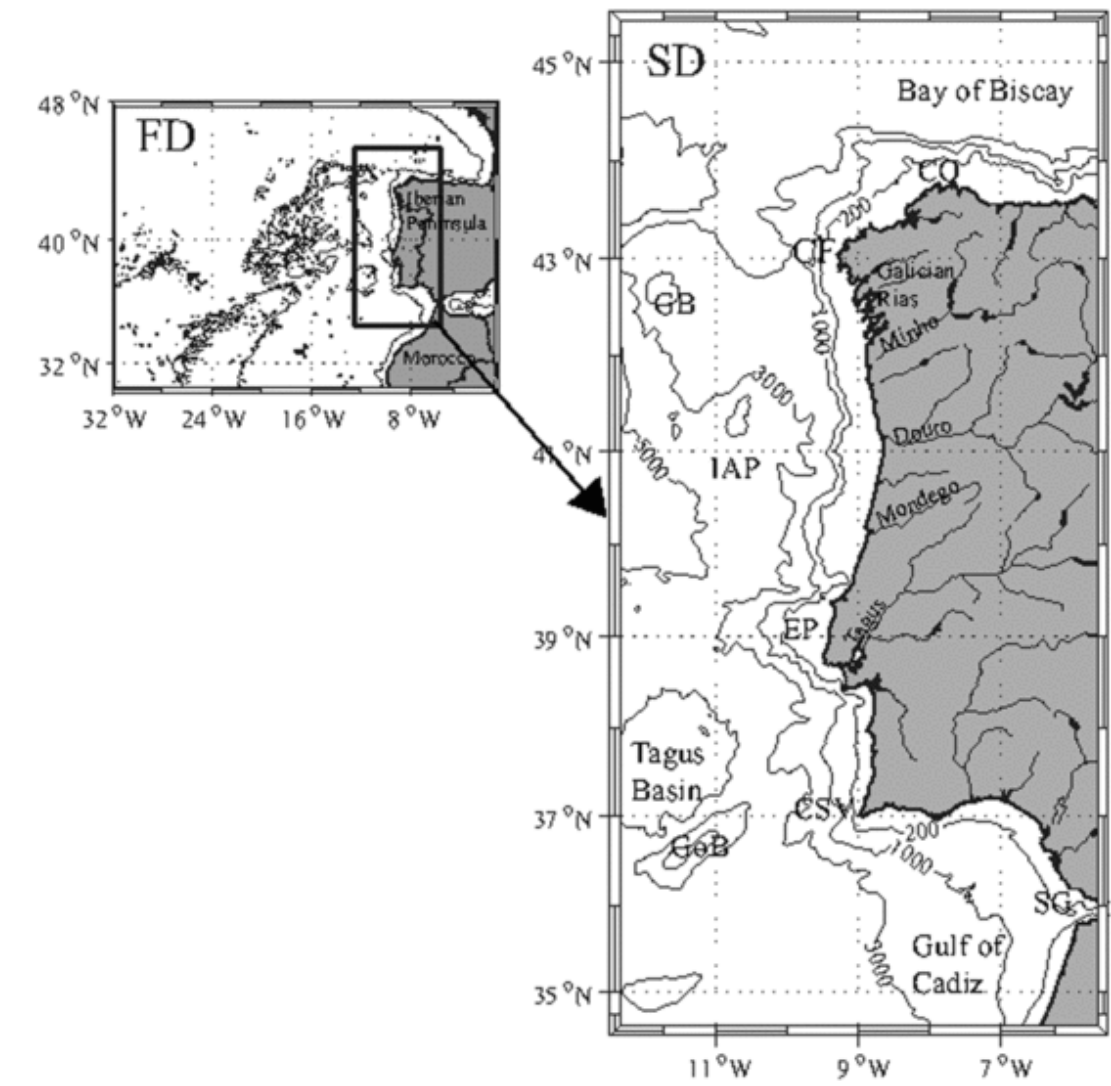

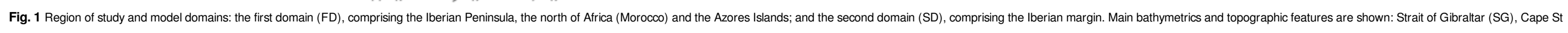
Vicente (CSV), Gorringe Bank (GoB), Estremadura Promontory (EP), Iberian Abyssal Plain (IAP), Galicia Bank (GB), Cape Finisterre (CF) and Cape Ortegal (CO).

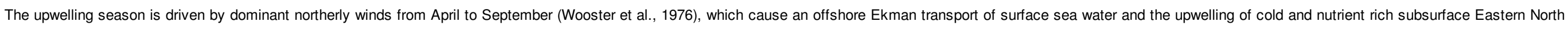

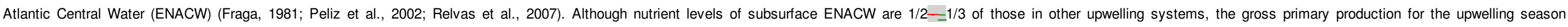

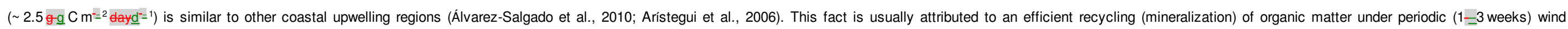

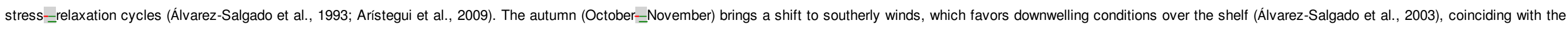

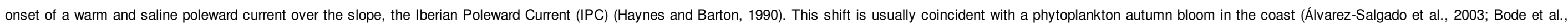

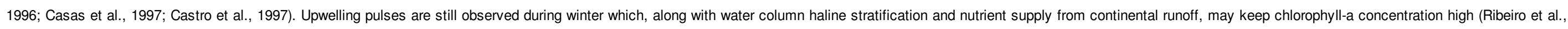

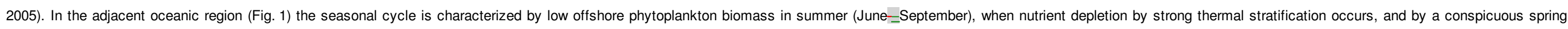
bloom, as part of the North Atlantic spring bloom (Longhurst, 1998).

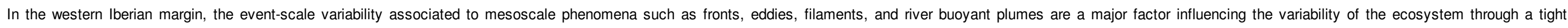

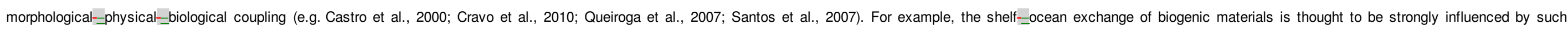

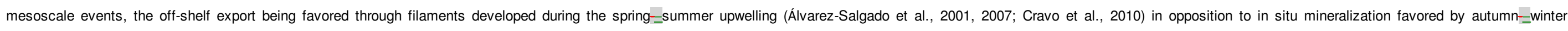

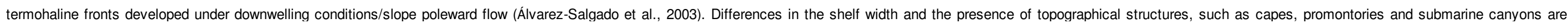




\section{ELSEVIER_MARSYS_2604}

related to spatial differences in the mesoscale activity (Relvas et al., 2007), which is thought to have effects on the spatial differences in the ecosystem along the Iberian margin (Cunha, 2002).

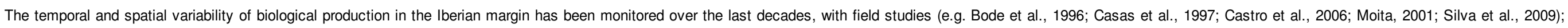

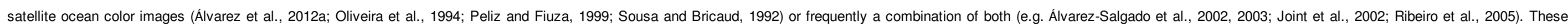

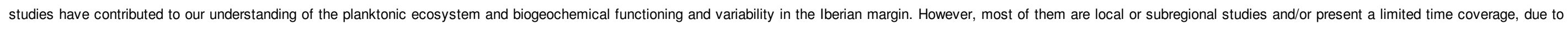

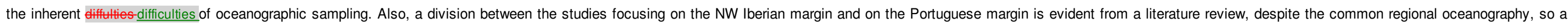

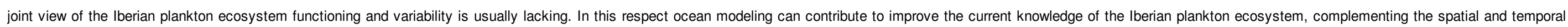

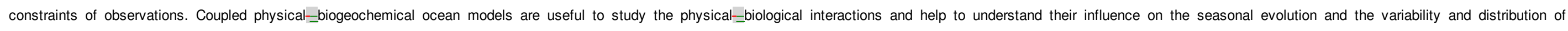

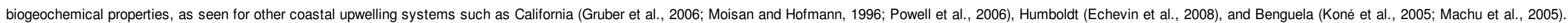

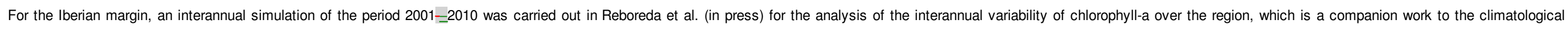
analysis presented in the current work.

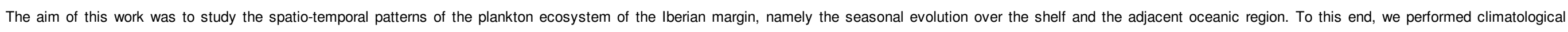

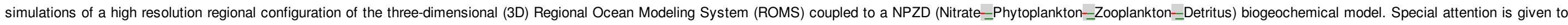

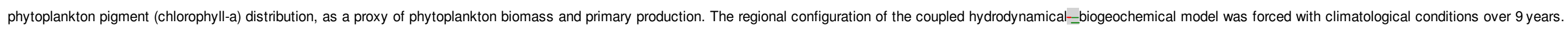

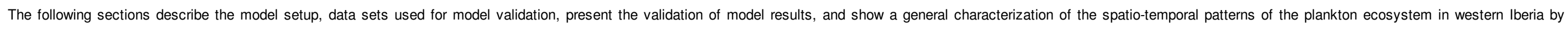
integrating model results and existing observations which so far were dispersed in the literature.

\section{Model setup}

\subsection{Hydrodynamic model}

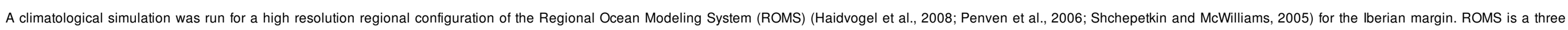

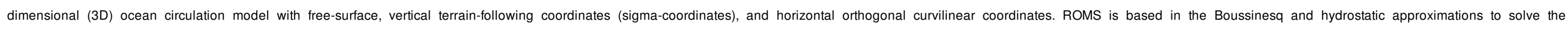

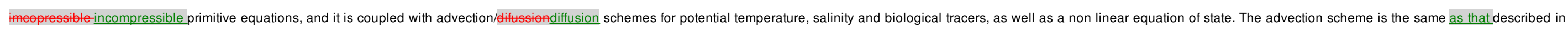

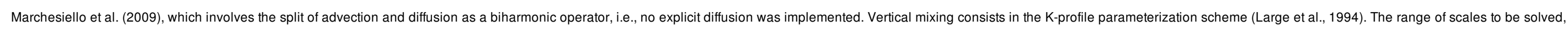

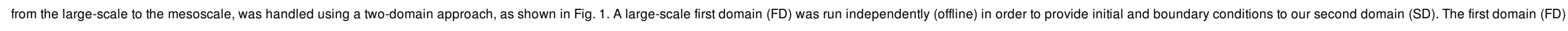

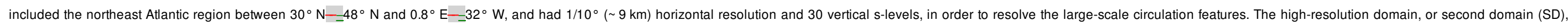

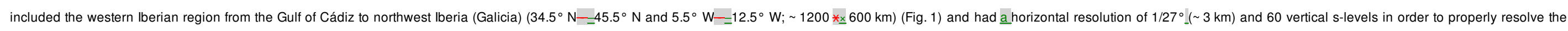

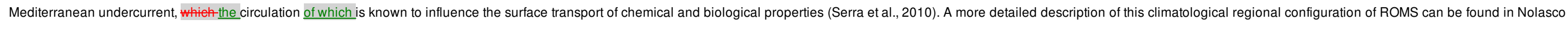
et al. (2013).

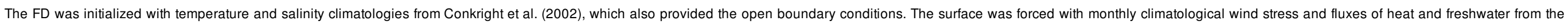

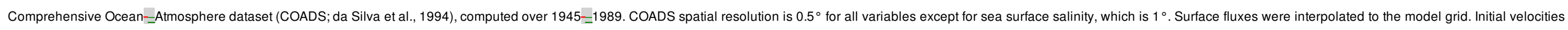

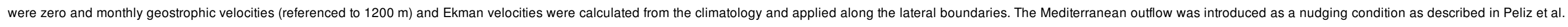

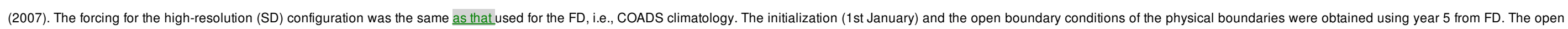

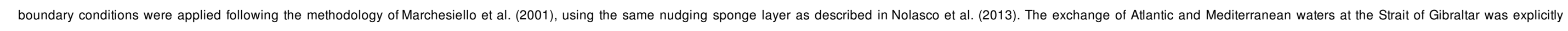
represented in the SD domain by the imposition of vertical profiles of temperature, salinity and zonal velocity at the 5 grid points at the Strait, similarly to Peliz et al. (2007).

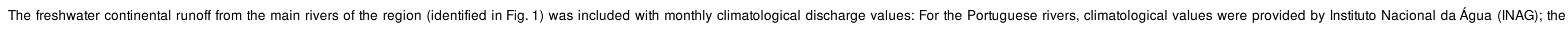
climatological discharge of the Galician rivers was obtained from (Río-Barja and Rodríguez-Lestegás, 1992).

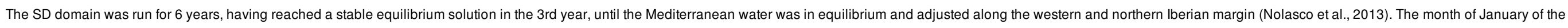




\section{ELSEVIER_MARSYS_2604}

7 th year run was chosen to initialize the biogeochemical model.

\subsection{Biogeochemical model}

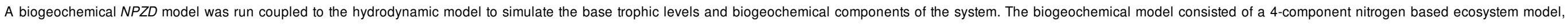

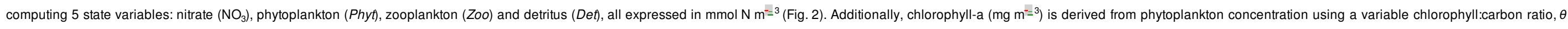

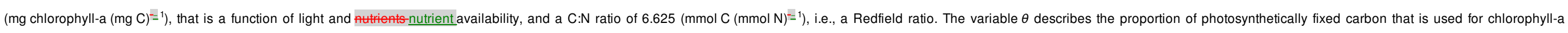

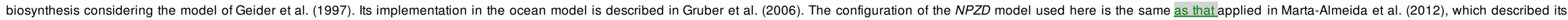
operational implementation and made a first model skill assessment for a trial period.

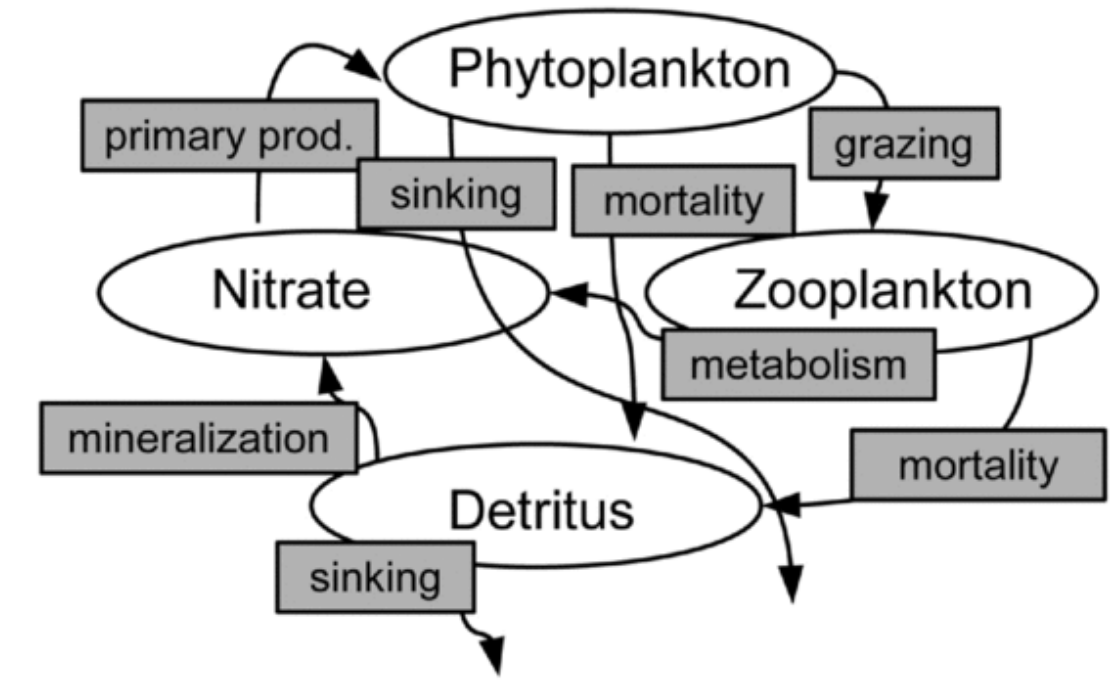

Fig. 2 Diagram of the NPZD model. Model state variables (nitrate, phytoplankton, zooplankton and detritus) are represented in terms of nitrogen concentration.

The 3D time evolution of the concentration of any of the biogeochemical variables $\left(B_{i}\right)$ is influenced by diffusion, horizontal advection, vertical mixing and the biogeochemical processes that act as sink or source for the variable:

$\frac{\partial B_{i}}{\partial t}=\nabla \cdot K \nabla B_{i}-u \cdot \nabla_{h} B_{i}-\left(W+w_{\text {simk }}\right) \frac{\partial B_{i}}{\partial z}+S M S\left(B_{i}\right)$

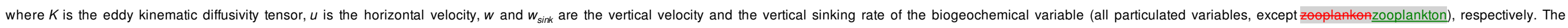
biogeochemical processes included in the source minus sink (SMS) term are specific for each variable.

The set of SMS equations for each of the biogeochemical variables is:

$S M S(N)=-\mu(P A R, T) \cdot \mu(N) \cdot P h y t+t_{D_{\text {Reth }}}$ Det $+t_{Z_{\text {rete }}} Z 0 o$

$S M S(P h y t)=\mu(P A R, T) \cdot \mu(N) \cdot P h y t-m_{p D} P h y t-g_{\max } Z o o \frac{P h y t}{K_{P}+P h y t}$

SMS(Zoo) $=\beta g_{\max } Z 00 \frac{\text { Phyt }}{K_{p}+P h y t}-m_{D_{D}} Z 00-t_{Z_{\operatorname{math}}} Z 00$

$S M S(D e t)=m_{F D} P h y t+m_{D D} Z o o+(1-\beta) g_{\max } Z 0 o \frac{P h y t}{K_{P}+P h y t}-t_{D_{R m i n}}$ Det

$\operatorname{SMS}(\theta)=\mu(P A R, T) \cdot \mu(N) \cdot\left(\frac{\mu(T) \cdot \mu(N) \cdot \theta_{\operatorname{mix}}}{\sqrt{\mu(T)^{2}+(\alpha \text { PAR } \theta)^{2}}}=0\right)$. 


\section{ELSEVIER_MARSYS_2604}

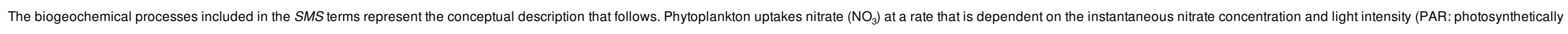
available radiation), and further constrained by temperature $(T)$. The nutrient $\left(\mathrm{NO}_{3}\right)$ limitation of the growth rate, $\mu\left(\mathrm{NO}_{3}\right)$, is calculated by a Michaelis=-Menten function

$\mu\left(\mathrm{NO}_{3}\right)=\frac{\mathrm{NO}_{3}}{\mathrm{~K}_{\mathrm{NO}_{3}}+\mathrm{NO}_{3}}$

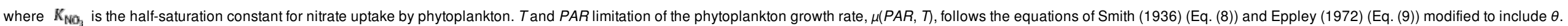
$\mu\left(P_{R}, T\right)=\frac{\mu(T) \cdot \alpha \cdot \operatorname{PAR} \cdot \theta}{\sqrt{\mu(T)^{2}+(\alpha \cdot P A R \cdot \theta)^{2}}}$

$\mu(T)=\ln 2 \cdot 0.851 \cdot(1.066)^{T}$

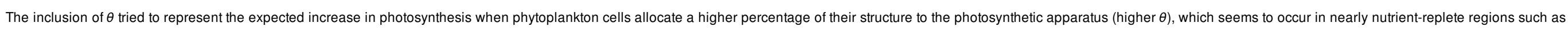

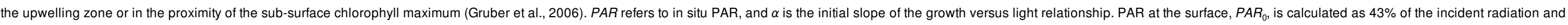
attenuated with depth as it is absorbed by water and chlorophyll,

PAR $=$ PAr $_{0} \cdot \exp \left(k_{w}+k_{\text {chta }} C h l\right) \Delta z$

where $k_{w}$ and $k_{c h l a}$ are attenuation coefficients for pure water and chlorophyll and $\Delta z$ is the depth step. PAR is given in $\mathrm{W} \mathrm{m}=2$. The total phytoplankton growth rate is written as $\mu=\mu(\operatorname{PAR}, T) \cdot \mu\left(\mathrm{NO}_{3}\right)$.

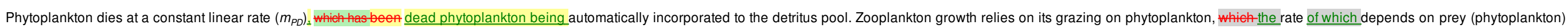
concentration, through a Michaelis-=Menten function,

$\mathrm{g}=\mathrm{g}_{\max } \frac{\text { Phyt }}{K_{P}+P h y t}$

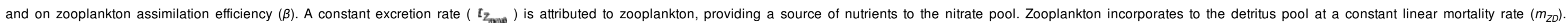

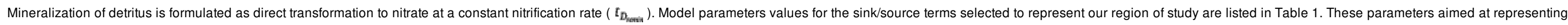

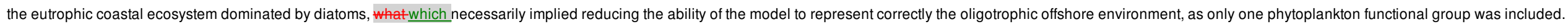

Table 1 Parameter values of the NPZD model.

\begin{tabular}{|c|c|c|c|}
\hline Parameter & & Value & Unit \\
\hline$K_{w}$ & Light attenuation in seawater & 0.04 & $m^{-1}$ \\
\hline$K_{\text {chla }}$ & Light attenuation by chlorophyll & 0.024 & $\left(\mathrm{~m}^{2} \mathrm{mg} \text { Chla }\right)^{-1}$ \\
\hline$\alpha$ & Initial slope of the $P-I$ curve & 1 & $\mathrm{mg} C\left(\mathrm{mg} \text { ChlaW } \mathrm{m}^{-2} \mathrm{~d}\right)^{-1}$ \\
\hline$\theta$ & Maximum cellular chlorophyll:C ratio & 0.03 & $\mathrm{mg}$ Chla $(\mathrm{mg} \mathrm{C})^{-1}$ \\
\hline$K_{\mathrm{NO}_{3}}$ & Half-saturation for phytoplankton $\mathrm{NO}_{3}$ uptake & 1.5 & $\mathrm{mmol} \mathrm{N} \mathrm{m}^{-3}$ \\
\hline$K_{p}$ & Zooplankton half-saturation constant for ingestion & 1 & $\mathrm{mmol} \mathrm{N} \mathrm{m}{ }^{-3}$ \\
\hline$g_{\max }$ & Maximum zooplankton growth rate & 0.9 & $d^{-1}$ \\
\hline$\beta$ & Zooplankton assimilation coefficient & 0.75 & n.d. \\
\hline$m_{P D}$ & Phytoplankton mortality rate & 0.03 & $d^{-1}$ \\
\hline
\end{tabular}




\section{ELSEVIER_MARSYS_2604}

\begin{tabular}{|l|l|}
$m_{Z D}$ & Zooplankton mortality rate \\
\hline$t_{\text {Zmetab }}$ & Zooplankton specific excretion rate \\
\hline$t_{\text {Dremin }}$ & Detrital mineralization to $\mathrm{NO}_{3}$ rate \\
\hline$w_{P}$ & Sinking velocity for phytoplankton \\
\hline$w_{D}$ & Sinking velocity for detritus \\
\hline
\end{tabular}

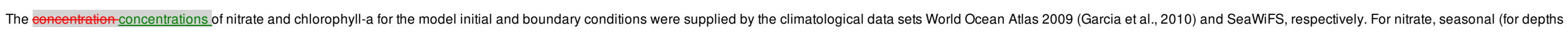

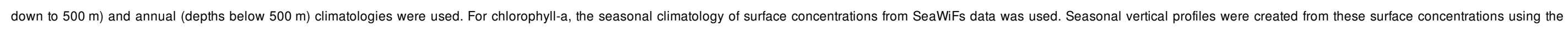

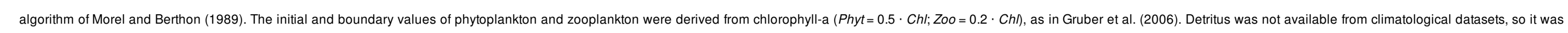

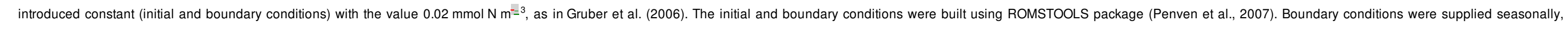

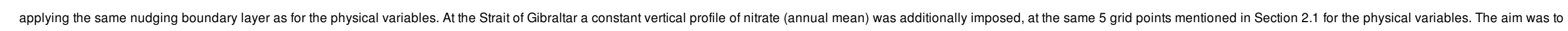

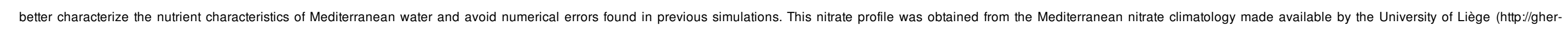
diva.phys.ulg.ac.be). The riverine inputs of nitrate and chlorophyll were constant

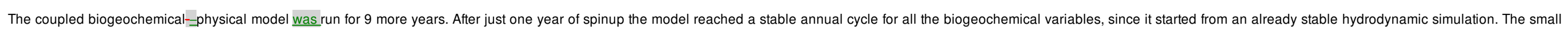

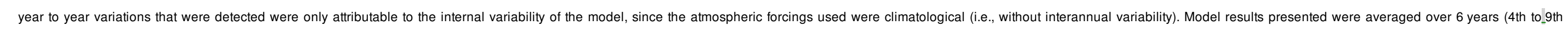
climatological years) in order to smooth this internal variability.

\subsection{Data sets for model evaluation}

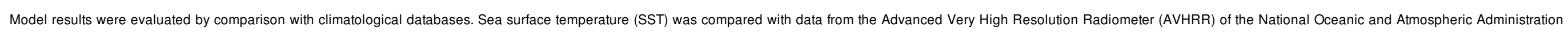

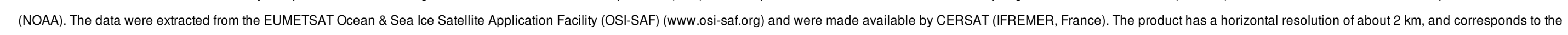

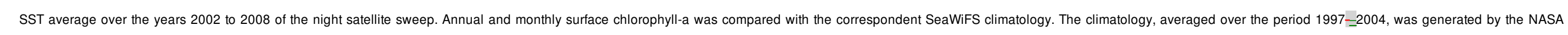
Goddard Space Flight Center (http://oceancolor.gsfc.nasa.gov). The horizontal resolution is $9 \mathrm{~km}$.

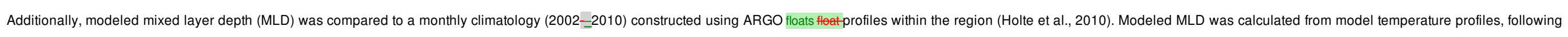
Lorbacher et al.'s (2006) criteria, and averaged over the model domain along one climatological year.

\section{Results}

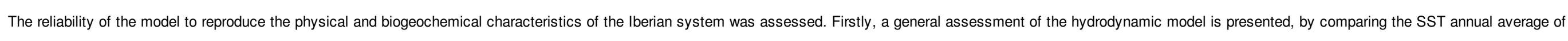

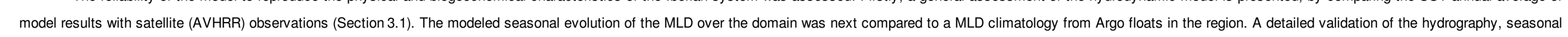

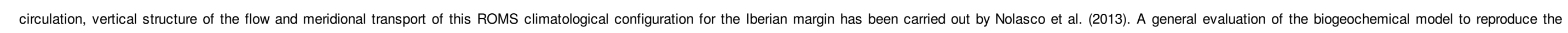

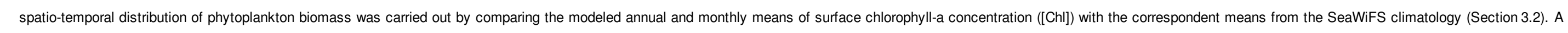
quantitative analysis of the MLD and chlorophyll-a comparisons was performed by plotting Taylor diagrams.

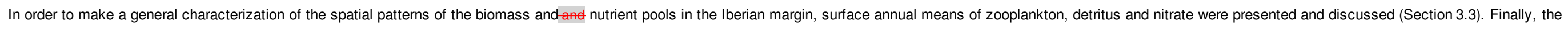
seasonal vertical distribution of chlorophyll, nitrate and detritus along the Iberian margin was analyzed through cross-shelf monthly means at three selected zonal sections (Section 3.4).

\subsection{Hydrodynamic model evaluation}

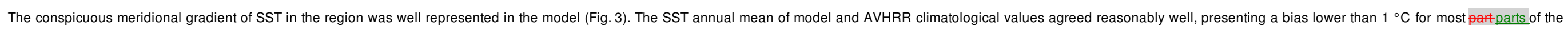

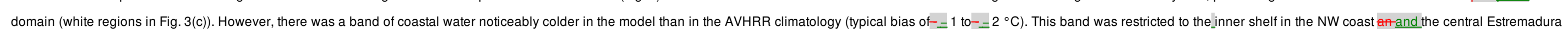




\section{ELSEVIER_MARSYS_2604}

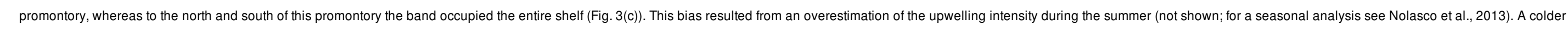

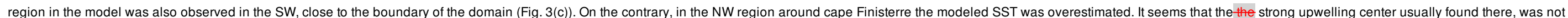
entirely reproduced by the model.

a)
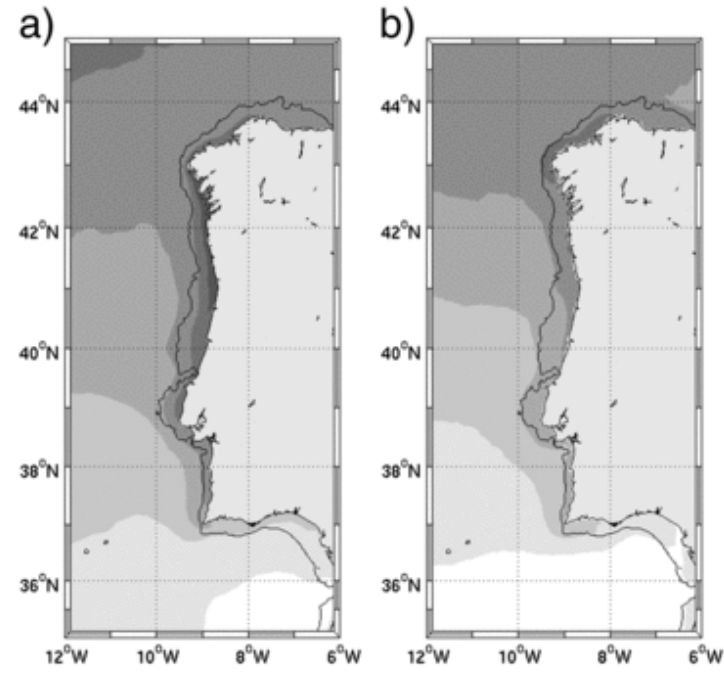

$\begin{array}{llllllllll}12 & 13 & 14 & 15 & 16 & 17 & 18 & 19 & 20\end{array}$

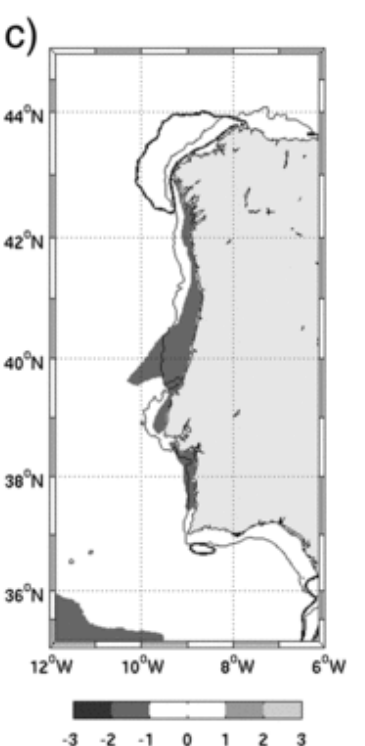

Fig. 3 Annual mean SST from ROMS model (a), from AVHRR climatology (b) and difference between them (model-AVHRR) (c). The $200 \mathrm{~m}$ isobath is shown.

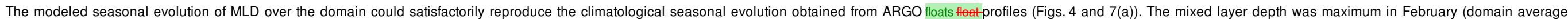

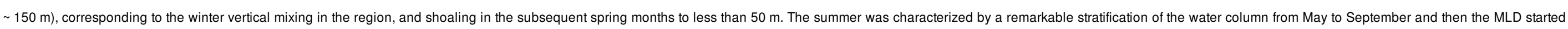

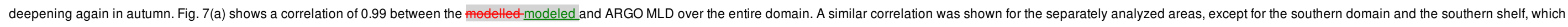

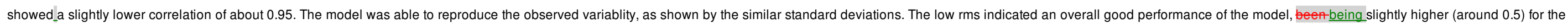
southern areas (Fig. 7(a)).

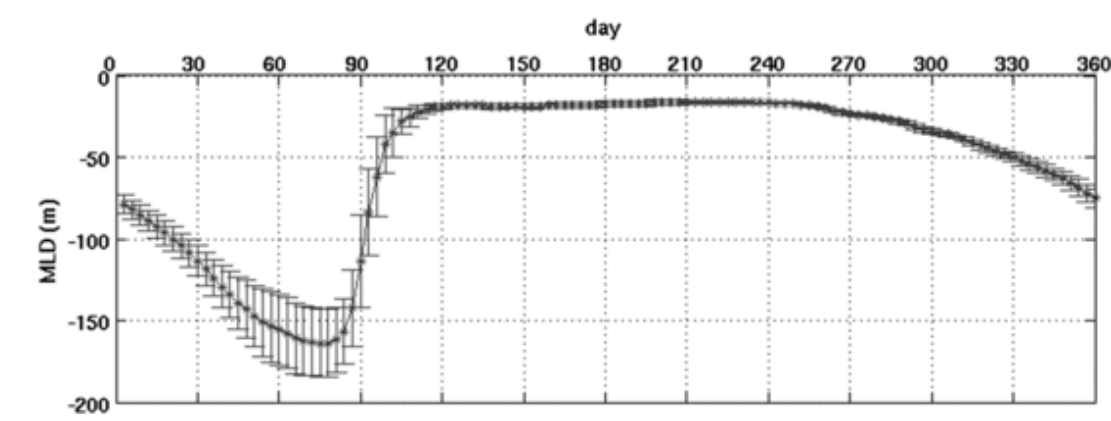

Fig. 4 Mixed layer depth $(\mathrm{m})$ annual cycle in the lberian margin (SD model domain) obtained from ROMS temperature profiles for the 6 th climatological year ( 3 days averages; mean $\pm \mathrm{sd}$ ).

\subsection{Evaluation of annual and seasonal [Chl] at the sea surface}

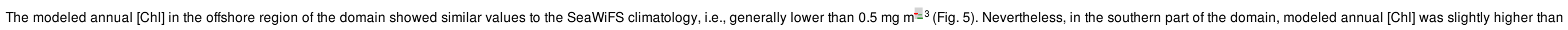

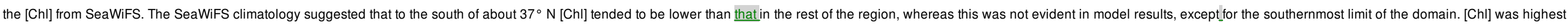




\section{ELSEVIER_MARSYS_2604}

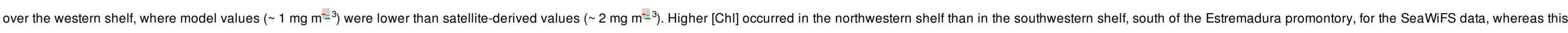

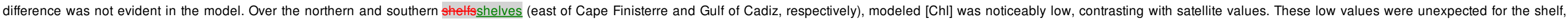
suggesting an underestimation of modeled [Chl] in these areas.

a)

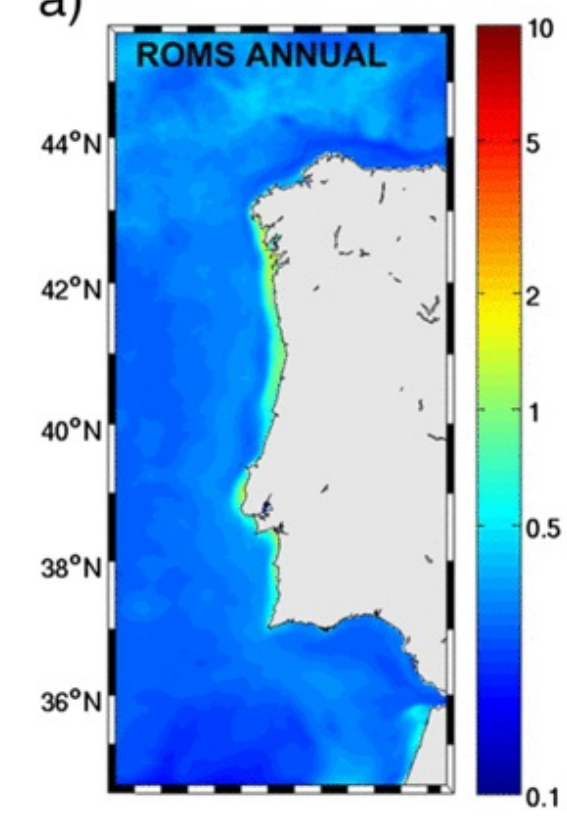

b)

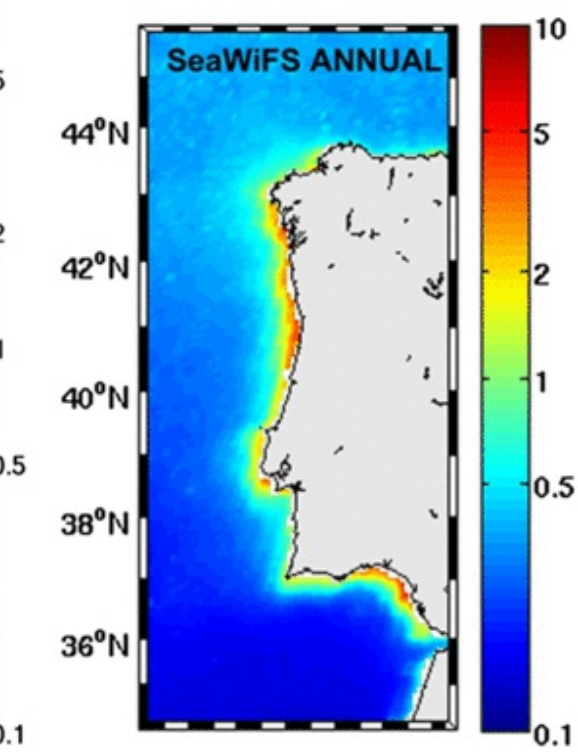

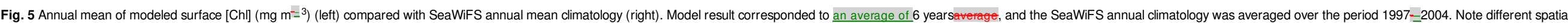

resolution resolutions in model and satellite fields.

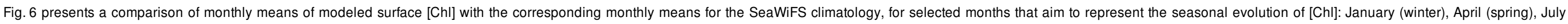

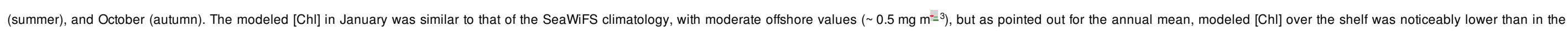

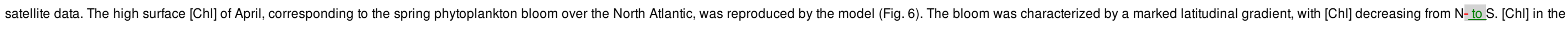

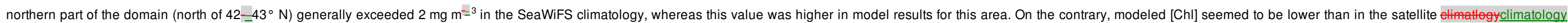

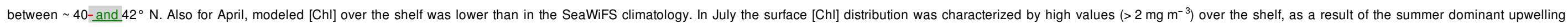

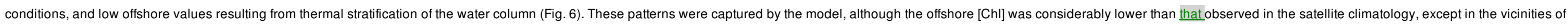

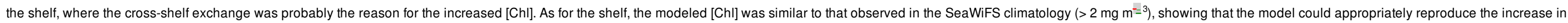

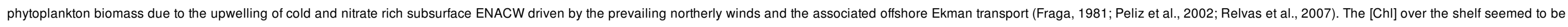

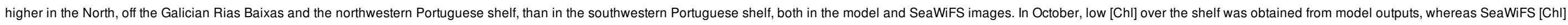

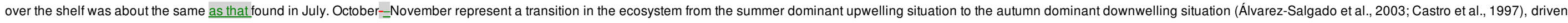

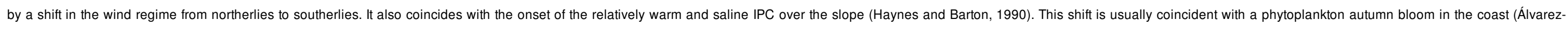

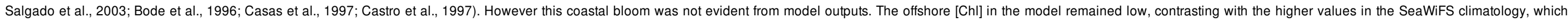

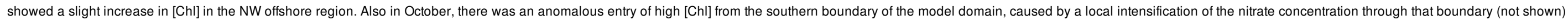
as a result of the local circulation. 


\section{ELSEVIER_MARSYS_2604}

Fig. 10 Cross-shelf vertical sections of modeled nitrate ( $\mathrm{mmol} \mathrm{N} \mathrm{m}=3$, color scale and solid contour line) across 3 locations in the western lberian margin: $42^{\circ} \mathrm{N}, 40^{\circ} \mathrm{N}$, and $38^{\circ} \mathrm{N}$.
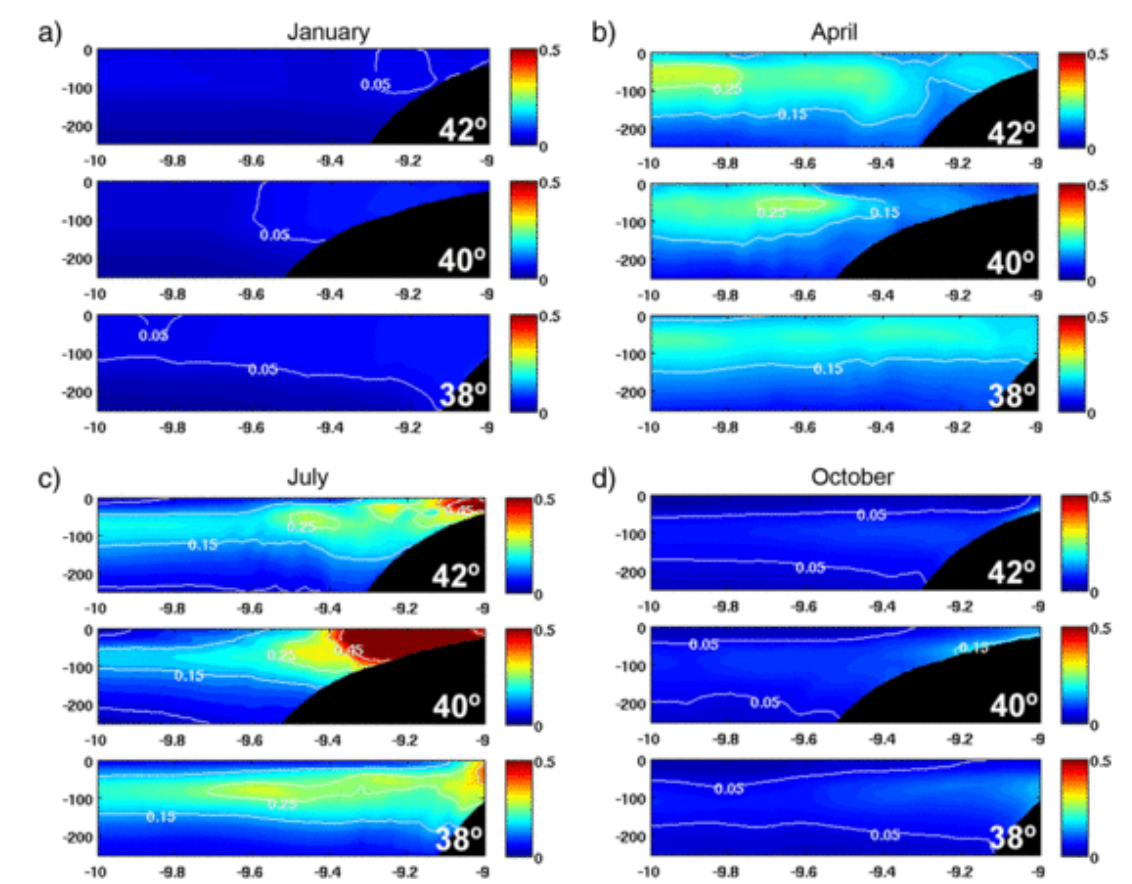

Fig. 11 Cross-shelf vertical sections of modeled detritus ( $m$ mol N m= $=3$, color scale and solid contour line) across 3 locations in the western lberian margin: $42^{\circ} \mathrm{N}, 40^{\circ} \mathrm{N}$, and $38^{\circ} \mathrm{N}$.

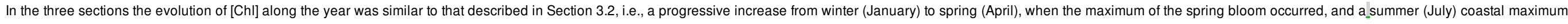

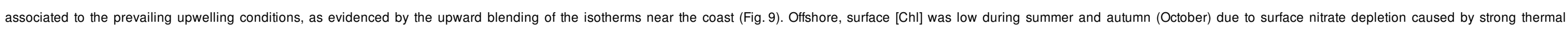

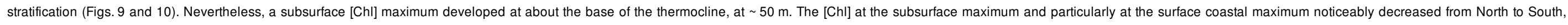

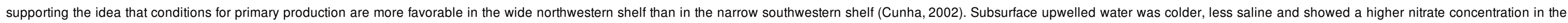

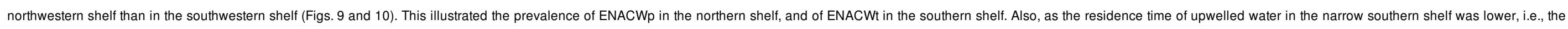

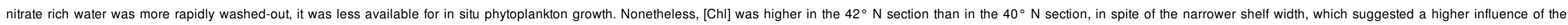
characteristics of the upwelled water than of the shelf width.

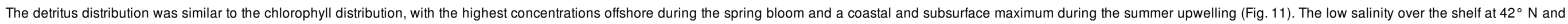

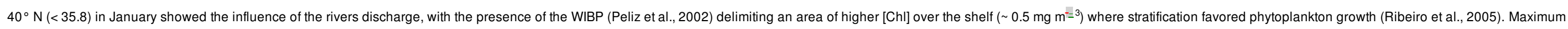
salinity cores showed the presence of the IPC in October and January in the vicinities of the shelf, although no evident effect on [Chl] could be detected from model results.

\section{Discussion}

\subsection{Model evaluation}

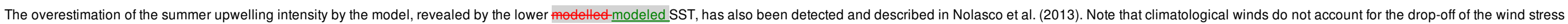

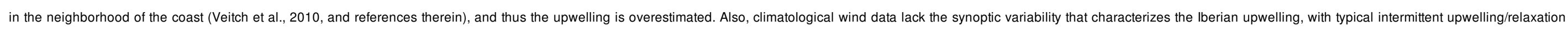

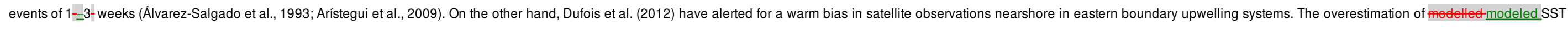

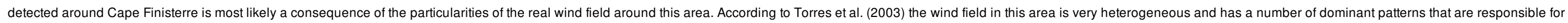




\section{ELSEVIER_MARSYS_2604}

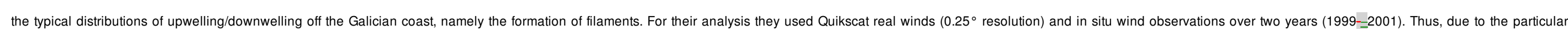
structure of the observed wind field, the climatological winds cannot properly reproduce the offshore extension of upwelling observed off NW Galicia, given its seasonal averaged nature.

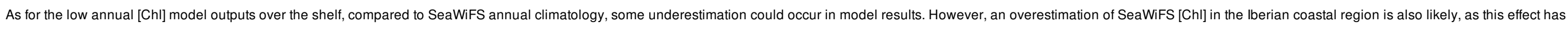

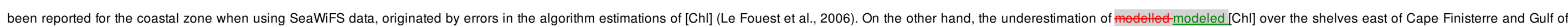

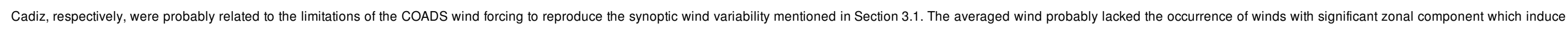

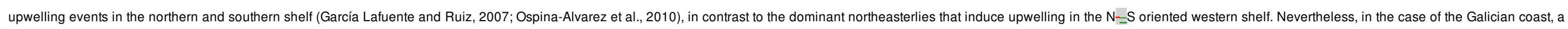

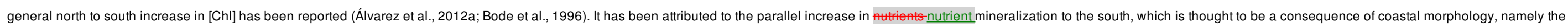
presence of the Rias Baixas, four large coastal embayments in the southwest Galician coast which export organic matter to the adjacent shelf (Álvarez-Salgado et al., 1993, 1997; Fraga, 1981; Prego et al., 1999).

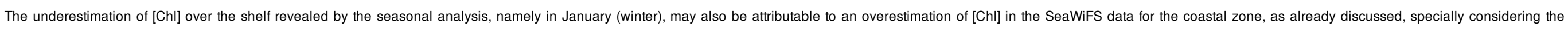

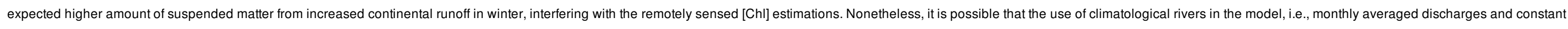

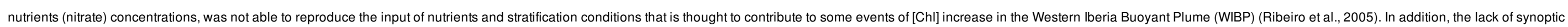

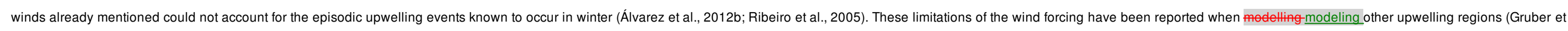
al., 2006).

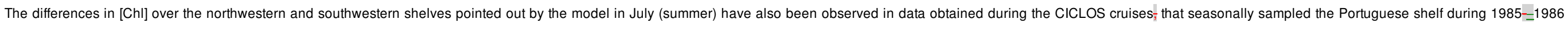

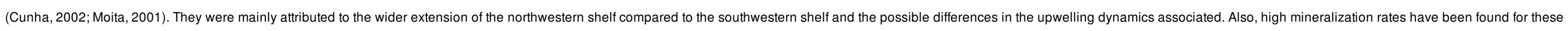
areas of the northwestern shelf, increasing the potential primary production (Álvarez-Salgado et al., 1997).

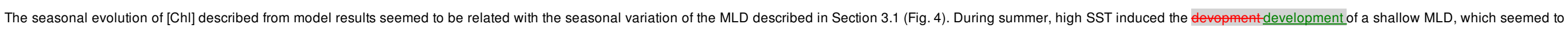

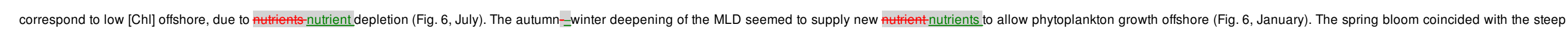
shoaling of the MLD (Fig. 6, April).

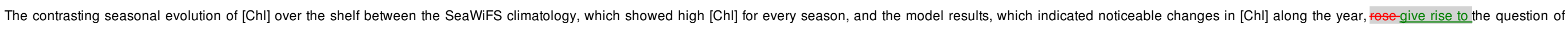

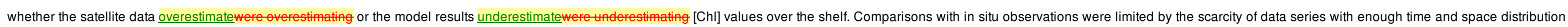

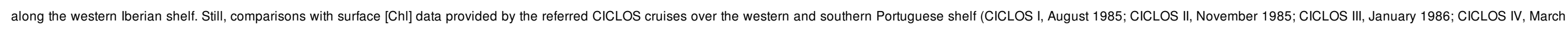

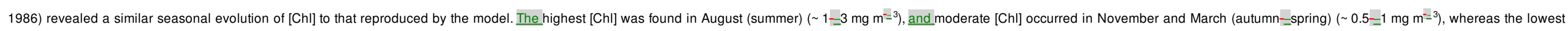

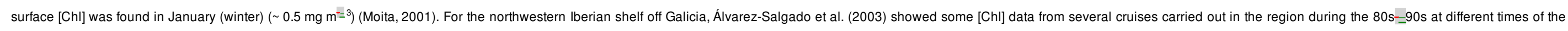

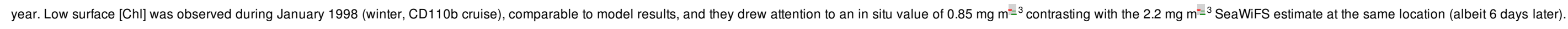

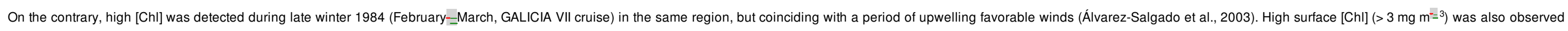

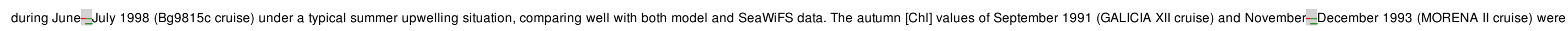

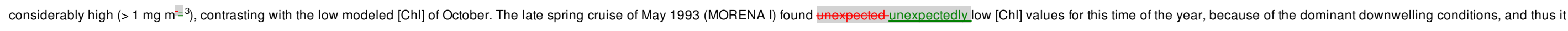

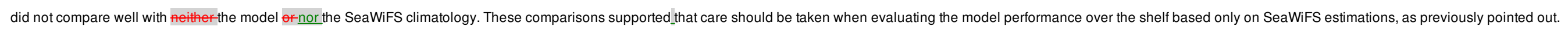

\subsection{Mean Zoo, Det and $\mathrm{NO}_{3}$ standing stocks at the sea surface}

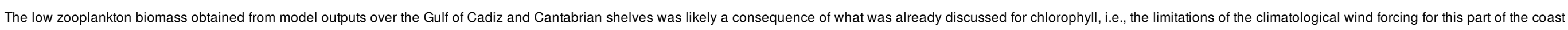
with a different orientation.

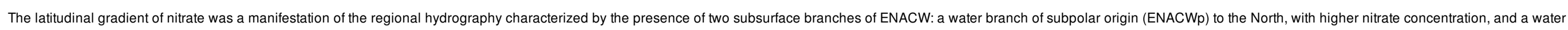

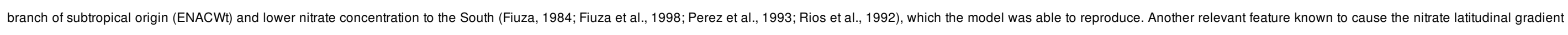
was the shallower winter vertical mixing in the south $(\sim 100 \mathrm{~m})$ compared to that in the north $(\sim 300 \mathrm{~m})$, resulting in a general northward increase in the nitrate concentration (Perez et al., 2005). 


\section{ELSEVIER_MARSYS_2604}

\subsection{Seasonal vertical distribution of $\mathrm{Chl}, \mathrm{NO}_{3}$ and Det along the western Iberian shelf}

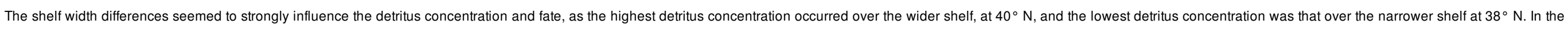

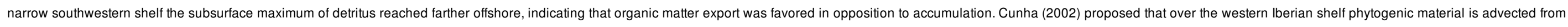

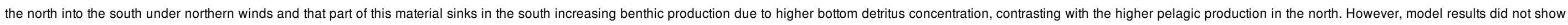

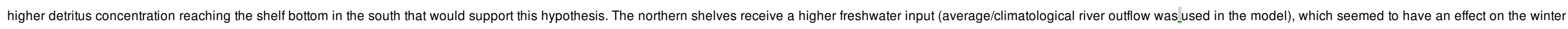
chlorophyll cross-shelf distribution (Fig. 9)

\section{Summary and conclusions}

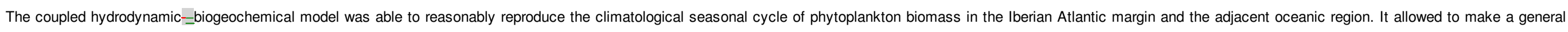

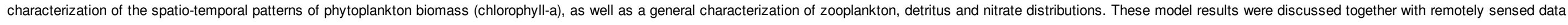

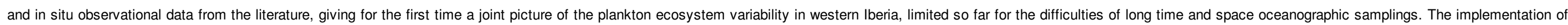

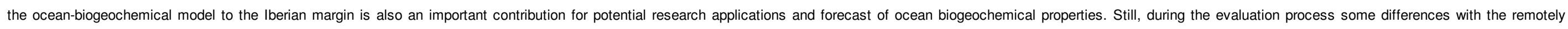

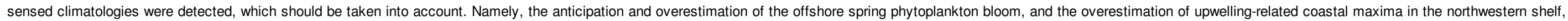

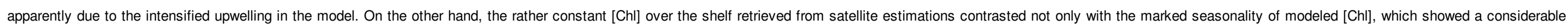

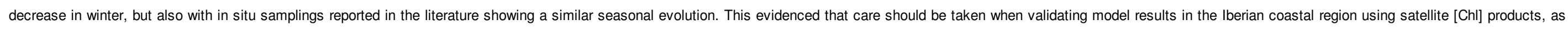
there seemed to be an overestimation in remotely sensed [Chl] values, particularly in winter.

\section{Acknowledgements}

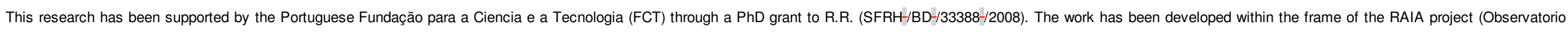

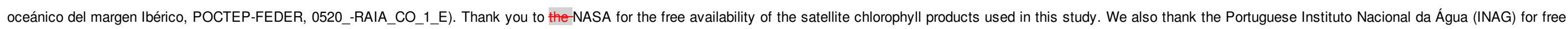
access to the available data on river discharges.

\section{References}

Álvarez I., Lorenzo M.N. and de Castro M., Analysis of chlorophyll-a concentration along the Galician coast: seasonal variability and trends, ICES J. Mar. Sci. 69 (5), $2012 a, 728-738$.

Álvarez I., Prego R., de Castro M. and Varela M., Galicia upwelling revisited: out-of-season events in the Rias (1967-_2009), Cienc. Mar. 38 (1B), $2012 b, 143-159$.

Álvarez-Salgado X.A., Roson G., Perez F.F. and Pazos Y., Hydrographic variability off the Rias Baixas (NW Spain) during the upwelling season, J. Geophys. Res. Oceans 98 (C8), $1993,14447-14455$.

Álvarez-Salgado X.A., Castro C.G., Perez F.F. and Fraga F., Nutrient mineralization patterns in shelf waters of the western Iberian upwelling, Cont. Shelf Res. 17 (10), $1997,1247-1270$.

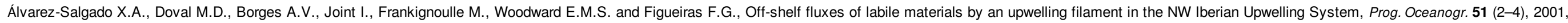
$321-337$.

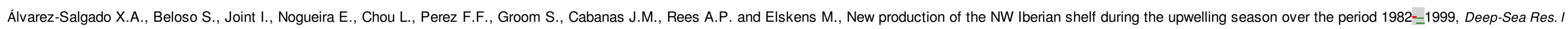
Oceanogr. Res. Pap. 49 (10), 2002, 1725-1739.

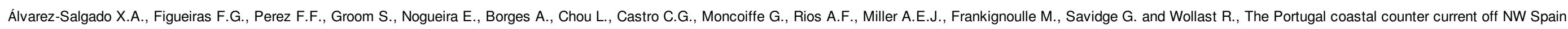
new insights on its biogeochemical variability, Prog. Oceanogr. 56 (2), 2003, 281-321.

Álvarez-Salgado X.A., Aristegui J., Barton E.D. and Hansell D.A., Contribution of upwelling filaments to offshore carbon export in the subtropical Northeast Atlantic Ocean, Limnol. Oceanogr. 52 (3), 2007 , 1287-1292.

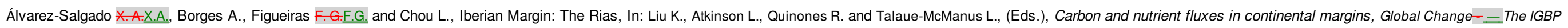




\section{ELSEVIER_MARSYS_2604}

series 2010, Springer-Verlag; Berlin Heidelberg, 102-119.

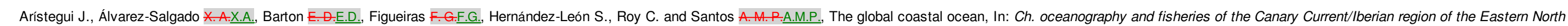
Atlantic, The Sea vol. 14, 2006, Harvard Univ. Press; Cambridge, Cambridge, 877-931.

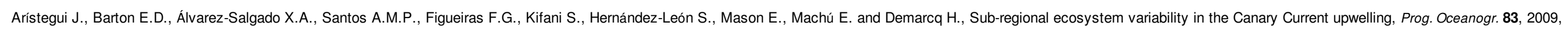
33-48.

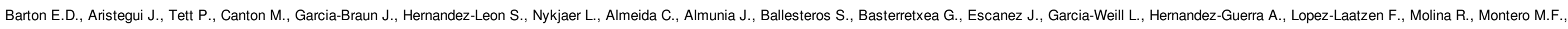
Navarro-Perez E., Rodriguez J.M., van Lenning K., Velez H. and Wild K., The transition zone of the Canary Current upwelling region, Prog. Oceanogr. 41 (4), $1998,455-504$.

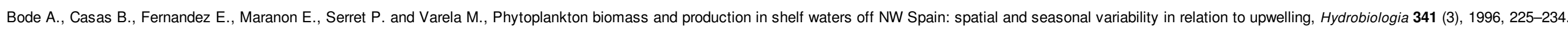

Casas B., Varela M., Canle M., Gonzalez N. and Bode A., Seasonal variations of nutrients, seston and phytoplankton, and upwelling intensity off La Coruna (NW Spain), Estuar. Coast. Shelf Sci. 44 (6), 1997, 767-778.

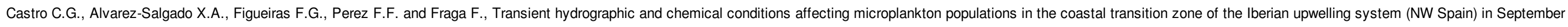
1986, J. Mar. Res. 55 (2), 1997, 321-352.

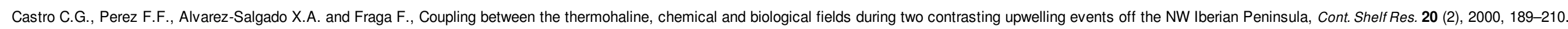

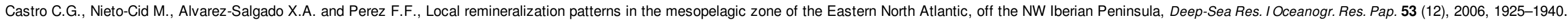

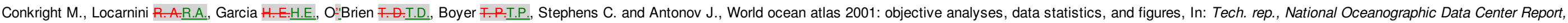
2002.

Cravo A., Relvas P., Cardeira S., Rita F., Madureira M. and Sánchez R., An upwelling filament off southwest lberia: effect on the chlorophyll a and nutrient export, Cont. Shelf Res. 30 (15), $2010,1601-1613$.

Cunha M.E., Physical control of biological processes in a coastal upwelling system, (PhD Thesis)2002, Universidade de Lisboa; Portugal.

da Silva A., Young A. and Levitus S., Atlas of surface marine data 1994, volume 1: algorithms and procedures, 1994.

Dufois F., Penven P., Whittle J. and Veitch J., On the warm nearshore bias in Pathfinder monthly SST products over Eastern Boundary Upwelling Systems, Ocean Model. 47, 2012, 113-118.

Echevin V., Aumont O., Ledesma J. and Flores G., The seasonal cycle of surface chlorophyll in the Peruvian upwelling system: a modelling study, Prog. Oceanogr. 79 (2-4), $2008,167-176$.

Eppley R.W., Temperature and phytoplankton growth in sea, Fish. Bull. 70 (4), 1972, 1063-1085.

Figueiras F.G., Labarta U. and Reiriz M.J.F., Coastal upwelling, primary production and mussel growth in the Rias Baixas of Galicia, Hydrobiologia 484 (1-3), $2002,121-131$.

Fiuza A.F.G., Hidrologia e dinámica das águas costeiras de Portugal, (phd thesis.Ph.D. thesis)1984, Universidade de Lisboa; Portugal.

Fiuza A.F.G., Demacedo M.E. and Guerreiro M.R., Climatological space and time-variation of the Portuguese coastal upwelling, Oceanol. Acta 5 (1), 1982, 31-40.

Fiuza A.F.G., Hamann M., Ambar I., del Rio G.D., Gonzalez N. and Cabanas J.M., Water masses and their circulation off western Iberia during May 1993, Deep-Sea Res. IOceanogr. Res. Pap. 45 (7), 1998, 1127-1160.

Fraga F., Upwelling off the Galician coast, Northwest Spain, In: Richards S.A., (Ed), Coastal Upwelling Series vol. 1, 1981, AGU; Washington DC, $176-182$.

García Lafuente J. and Ruiz J., The Gulf of Cádiz pelagic ecosystem: a review, Prog. Oceanogr. 74, 2007, 228-251.

Garcia H.E., Locarnini R.A., Boyer T., Antonov J., Zweng M., Baranova O. and Johnson D., World Ocean Atlas 2009, Volume 4: Nutrients (Phosphate, Nitrate, Silicate), 2010.

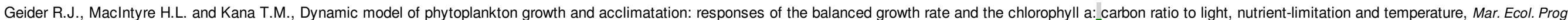
Ser. 148, 1997, 187-200 


\section{ELSEVIER_MARSYS_2604}

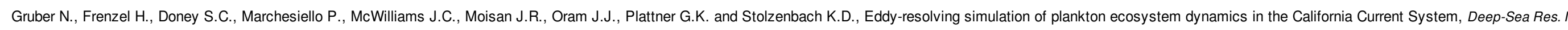
Oceanogr. Res. Pap. 53 (9), 2006, 1483-1516.

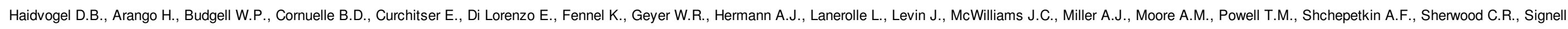
R.P., Warner J.C. and Wilkin J., Ocean forecasting in terrain-following coordinates: formulation and skill assessment of the regional ocean modeling system, J. Comput. Phys. 227 (7), $2008,3595-3624$.

Haynes R. and Barton E.D., A poleward flow along the Atlantic coast of the Iberian Peninsula, J. Geophys. Res. Oceans 95 (C7), 1990, 11425-11441.

Holte J., Gilson J., Talley L. and Roemmich D., Argo mixed layers, 2010, Scripps Institution of Oceanography/UCSD, (http://mixedlayer.ucsd.edu).

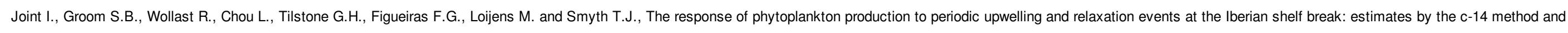
by satellite remote sensing, J. Mar. Syst. 32 (1-3), 2002, 219-238.

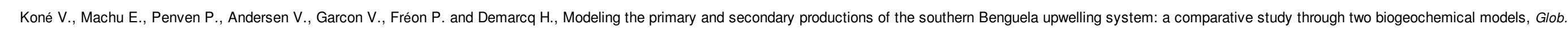
Biogeochem. Cycles 19 (4), 2005, GB4021, http://dx.doi.org/10.1029/2004GB002427.

Large W.G., Mcwilliams J.C. and Doney S.C., Oceanic vertical mixing-_a review and a model with a nonlocal boundary-la-yer parameterization, Rev. Geophys. 32 (4), $1994,363-403$.

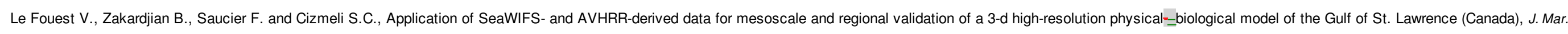
Syst. 60, 2006, 30-50.

Longhurst A.R., Ecological Geography of the Sea, 1998, Academic Press.

Lorbacher K., Dommenget D., Niiler P.P. and Köhl A., Ocean mixed layer depth: a subsurface proxy of ocean-_atmosphere variability, J. Geophys. Res. 111 (C7), 2006, C07010.

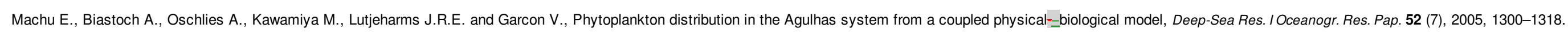

Marchesiello P., McWilliams J.C. and Shchepetkin A., Open boundary conditions for long-term integration of regional oceanic models, Ocean Model. 3 (1), $2001,1-20$.

Marchesiello P., Debreu L. and Couvelard X., Spurious diapycnal mixing in terrain-following coordinate models: the problem and a solution, Ocean Model. 26 (3-4), $2009,156-169$.

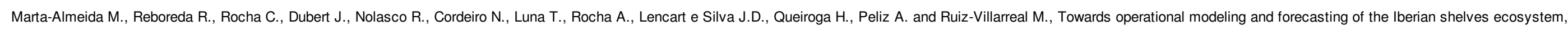
PLOS ONE 7 (5), 2012, e37343.

Moisan J.R. and Hofmann E.E., Modeling nutrient and plankton processes in the California coastal transition zone._1. A time- and depth-dependent model, J. Geophys. Res. Oceans 101 (C10), 1996, 22647-22676.

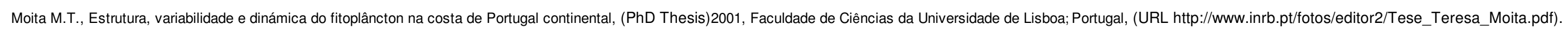

Morel A. and Berthon J.F., Surface pigments, algal biomass profiles, and potential production of the euphotic layer: relationships reinvestigated in view of remote-sensing application, Limnol. Oceanogr. 34, 1989, 1545-1562.

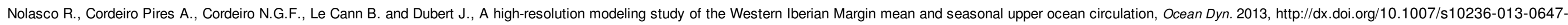
8, (Published online).

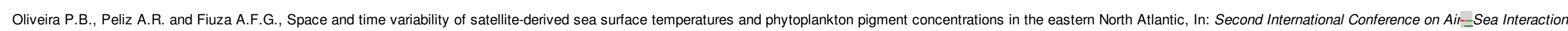
and on Meteorology and Oceanography of the Coastal Zone, 1994, 300-301, (311).

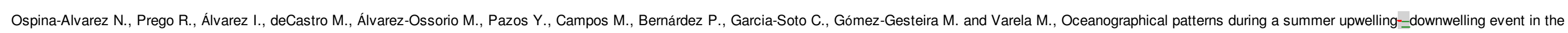
Northern Galician Rias: comparison with the whole Ria system (NW of Iberian Peninsula), Cont. Shelf Res. 30 (12), 2010, 1362-1372.

Peliz A.J. and Fiuza A.F.G., Temporal and spatial variability of CZCS-derived phytoplankton pigment concentrations off the western Iberian Peninsula, Int. J. Remote Sens. 20 (7), 1999 , $1363-1403$. 


\section{ELSEVIER_MARSYS_2604}

Peliz A., Rosa T.L., Santos A.M.P. and Pissarra J.L., Fronts, jets, and counter-flows in the Western Iberian upwelling system, J. Mar. Syst. 35 (1-2), $2002,61-77$.

Peliz A., Dubert J., Marchesiello P. and Teles-Machado A., Surface circulation in the Gulf of Cadiz: model and mean flow structure, J. Geophys. Res. Oceans 112, 2007, C11015, http://dx.doi.org/10.1029/2007jc004159.

Penven P., Debreu L., Marchesiello P. and McWilliams J.C., Evaluation and application of the ROMS 1-way embedding procedure to the central California upwelling system, Ocean Model. 12 (1-2), $2006,157-187$.

Penven P., Marchesiello P., Debreu L. and Lefevre J., Software tools for pre- and post-processing of oceanic regional simulations, Environ. Model. Softw. 23 (5), 2007, 660-662.

Perez F.F., Mourino C., Fraga F. and Rios A.F., Displacement of water masses and remineralization rates off the Iberian Peninsula by nutrient anomalies, J. Mar. Res. 51 (4), 1993 , 869-892.

Perez F.F., Castro C.N.G., Rios A.F. and Fraga F., Chemical properties of the deep winter mixed layer in the Northeast Atlantic (40--47 degrees N), J. Mar. Syst. 54 (1-4), $2005,115-125$.

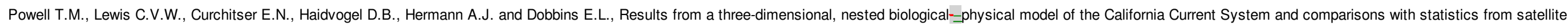
imagery, J. Geophys. Res. Oceans 111 (C7), 2006.

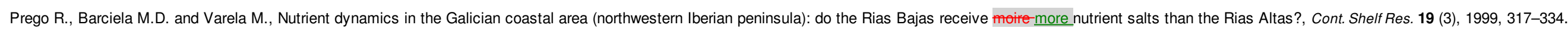

Queiroga H., Silva C., Sorbe J.C. and Morgado F., Composition and distribution of zooplankton across an upwelling front on the northern Portuguese coast during summer, Hydrobiologia 545, 2005, 195-207.

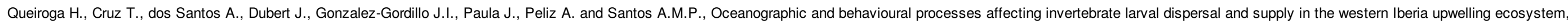
Prog. Oceanogr. 74 (2-3), 2007, 174-191.

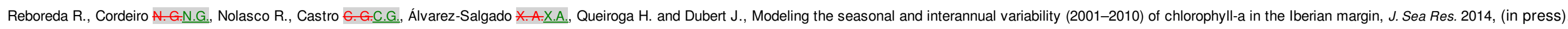

Relvas P., Barton E.D., Dubert J., Oliveira P.B., Peliz A., da Silva J.C.B. and Santos A.M.P., Physical oceanography of the western Iberia ecosystem: latest views and challenges, Prog. Oceanogr. 74 (2-3), 2007, 149-173.

Ribeiro A.C., Peliz A. and Santos A.M.P., A study of the response of chlorophyll-a biomass to a winter upwelling event off western Iberia using SeaWiFS and in situ data, J. Mar. Syst. 53 (1-4), $2005,87-107$.

Río-Barja F. and Rodríguez-Lestegás F., Os ríos galegos. Morfoloxía e réxime, 1992, Consello da Cultura Galega; Santiago de Compostela.

Rios A.F., Perez F.F. and Fraga F., Water masses in the upper and middle North-Atlantic ocean East of the Azores, Deep-Sea Res. A Oceanogr. Res. Pap. 39 (3-4A), $1992,645-658$.

Santos A.M.P., Kazmin A.S. and Peliz A., Decadal changes in the Canary Upwelling System as revealed by satellite observations: their impact on productivity, J. Mar. Res. 63 (2), 2005 , 359-379.

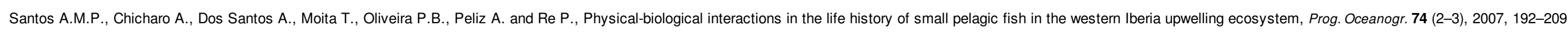
Serra N., Ambar I. and Boutov D., Surface expression of Mediterranean Water dipoles and their contribution to the shelf/slope-open ocean exchange, Ocean Sci. 6 (1), $2010,191-209$.

Shchepetkin A.F. and McWilliams J.C., The regional oceanic modeling system (ROMS): a split-explicit, free-surface, topography-following-coordinate oceanic model, Ocean Model. 9 (4), 2005, 347-404.

Silva A., Palma S., Oliveira P.B. and Moita M.T., Calcidiscus quadriperforatus and Calcidiscus leptoporus as oceanographic tracers in Lisbon bay (Portugal), Estuar. Coast. Shelf Sci. 81 (3), 2009, 333-344.

Smith E., Photosynthesis in relation to light and carbon dioxide, Proc. Natl. Acad. Sci. 22, 1936, 504-511.

Sousa F.M. and Bricaud A., Satellite-derived phytoplankton pigment structures in the Portuguese upwelling area, J. Geophys. Res. Oceans 97 (C7), 1992, 11343-11356.

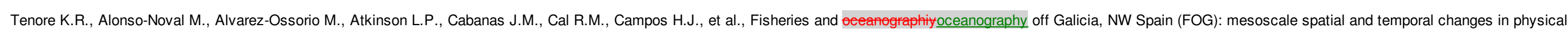
processes and resultant patterns of biological productivity, J. Geophys. Res. 100, 1995, 10943-10966.

Torres R., Barton E.D., Miller P. and Fanjul E., Spatial patterns of wind and sea surface temperature in the Galician upwelling region, J. Geophys. Res. 108 (C4), $2003,3130$.

Veitch J., Penven P. and Shillington F.A., Modeling equilibrium dynamics of the Benguela Current System, J. Phys. Oceanogr. 40, 2010, $1942-1964$.

Wooster W.S., Bakun A. and Mclain D.R., Seasonal upwelling cycle along Eastern boundary of North-Atlantic, J. Mar. Res. 34 (2), 1976, 131-141. 


\section{Highlights}

- A NChIPZD biogeochemical model was implemented to the Iberian margin.

- Model results were discussed together with remotely sensed data and in situ observations.

- A characterization of the seasonal cycle of the plankton ecosystem is presented.

- Over the shelf, a general north-to-south decrease in plankton biomass was detected.

- Differences in the shelf width influenced the offshore export of detritus.

\section{Queries and Answers}

Query:

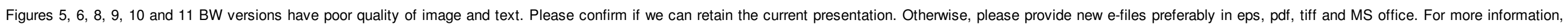
visit Elsevier website at: http://www.elsevier.com/author-schemas/artwork-and-media-instructions/.

Answer: I've attached BW figures with better quality

Query:

Please confirm that given names and surnames have been identified correctly.

Answer: Confirmed

Query:

This sentence has been slightly modified for clarity. Please check that the meaning is still correct, and amend if necessary

\section{Answer: Correct}

Query:

Ab en-dash was inserted between the words "physical" and "biological". Please check and correct if needed.

\section{Answer: Correct}

Query:

This sentence has been slightly modified for clarity. Please check that the meaning is still correct, and amend if necessary

\section{Answer: Correct}

Query:

This sentence has been slightly modified for clarity. Please check that the meaning is still correct, and amend if necessary. 


\title{
ELSEVIER_MARSYS_2604
}

\section{Query:}

This sentence has been slightly modified for clarity. Please check that the meaning is still correct, and amend if necessary.

\section{Answer: Correct}

Query:

This sentence has been slightly modified for clarity. Please check that the meaning is still correct, and amend if necessary.

\author{
Answer: Correct
}

Query:

This sentence has been slightly modified for clarity. Please check that the meaning is still correct, and amend if necessary.

\section{Answer: Amended}

Query:

This sentence has been slightly modified for clarity. Please check that the meaning is still correct, and amend if necessary.

\section{Answer: Correct}

\section{Query:}

This sentence has been slightly modified for clarity. Please check that the meaning is still correct, and amend if necessary.

\section{Answer: Correct}

Query:

This sentence has been slightly modified for clarity. Please check that the meaning is still correct, and amend if necessary.

\section{Answer: Amended}

Query:

Please provide an update for reference "Reboreda et al., in press".

Answer: The reference is still in press 